\title{
Heroicidad e identidad en la novela helenística Quéreas y Calírroe
}

\author{
Heroicity and identity in the Hellenistic novel Quéreas and Calírroe
}

\author{
Nazira Álvarez Espinoza \\ Escuela de Filología, Lingüística y Literatura \\ Universidad de Costa Rica
}

\section{Resumen}

En el contexto social y cultural del mundo helenístico, surge una nueva heroicidad. Esta representación ficcional modifica los modelos tradicionales masculinos y femeninos. Los cambios se pueden evidenciar en la novela de Caritón de Afrodisias, Quéreas y Calírroe. El texto es considerado el más antiguo del género. La representación de los protagonistas pone a prueba la dicotomía de los espacios tradicionales asignados a hombres y mujeres. Los espacios geográficos y sociales, las delimitaciones materiales y simbólicas, y las diferencias en las jerarquías de género se subvierten y modifican temporalmente cuando Quéreas y Calirroe se enfrentan a los obstáculos de la aventura. El análisis se realiza desde una perspectiva espacial asociada a los conceptos de la identidad, las fronteras, los límites, la ciudadanía, la xenia, el exilio y la liminalidad.

Palabras clave: espacio, género, héroes, geografía alejandrina

\begin{abstract}
In the social and cultural context of the Hellenistic world a new heroic model surface. The fictional representation modifies the traditional role models of femininity and masculinity. The changes may be observed in the novel of Chariton of Aphrodisias Chaereas and Callirhoe, considered the oldest text of the genre novel. The representation of the protagonists tests the dichotomy of the traditional spaces assigned for men and women. Hence the geographic and social spaces and the material and symbolic limitations, and the differences in gender hierarchies are subverted and interchanged temporarily by Chaereas and Callirhoe in order to overcome the obstacles of their adventure. The analysis is made from a spatial perspective associated with the concepts of space, identity, frontiers, limits, borders, citizenship, xenia, exile and liminality.
\end{abstract}


Keywords: space, gender, heroes, alexandrian geography

\section{La novela helenística}

$\mathrm{L}$ a novela helenística incorpora como eje temático el amor romántico y las peripecias que obstaculizan la unión de los amantes. Si bien podría pensarse como un antecedente lejano el regreso de Odiseo a Ítaca en la Odisea por las aventuras que enfrenta el protagonista para su regreso al hogar, el contexto social y cultural del mundo alejandrino presenta una heroicidad novedosa, alejada del heroísmo tradicional, que modifica los modelos tradicionales masculinos y femeninos. Los cambios en la representación de los protagonistas masculinos de la novela contrasta con el modelo épico tradicional, en el cual el héroe es activo y se convierte en el eje central de la trama. En la novela, el héroe comparte protagonismo con la figura femenina que asume un rol activo mientras que el Quéreas se muestra pasivo. Los espacios delimitados por la tradición social se interrelacionan e intercambian en el mundo alejandrino.

Los protagonistas de la novela no pertenecen al mundo mítico-legendario: son jóvenes de orígenes modestos o, en ocasiones, de una posición económica elevada que viven en un mundo cotidiano alejado de los entornos fantásticos de la heroicidad épica.

Un elemento interesante en este nuevo género helénico es el protagonismo inesperado que adquieren las jóvenes enamoradas al ser separadas de sus amantes. Ellas, por diferentes circunstancias, deben abandonar la pasividad modélica femenina y enfrentar múltiples y diversos obstáculos. Ellas, con frecuencia, son alejadas de la seguridad del entorno familiar. Así, desprovistas de toda protección, deben recurrir a sus propias habilidades e inteligencia para poder regresar con la persona que aman.

La novela de Caritón de Afrodisias, Quéreas y Calírroe, es considerada como la novela griega más antigua de las obras conservadas. El argumento relata las aventuras y desventuras de dos jóvenes amantes separados en Siracusa, cuyo peregrinaje los lleva fuera de la geografía de la Hélade. Quéreas y Calírroe deben sobrevivir en circunstancias que ponen a prueba la dicotomía de los espacios tradicionales asignados a hombres y mujeres.

Desde la antigüedad, las normas sociales del mundo griego distribuyeron los lugares en función de las conceptualizaciones de las acciones, los papeles y los valores asociados con lo femenino y lo masculino, la naturaleza y la cultura, la maternidad y la política. A partir de estas limitaciones, que inciden en la construcción de las relaciones de poder, se delimitaron espacios dentro y fuera del hogar asignados a los roles de género.

El presente artículo pretende analizar la representación de la heroicidad de los protagonistas de la novela helenística en el espacio geográfico y social determinado por las las jerarquías de género. La aproximación a los personajes de la novela griega se realiza desde una perspectiva espacial 
en función del poder y las relaciones sociales. Estas se encuentran asociadas con el espacio, la identidad, las fronteras, los límites, la ciudadanía, la xenia, el exilio y la liminalidad.

\section{La novela helenística}

Las primeras novelas griegas surgen durante la época helenística y, por sus características particulares, no se pueden clasificar dentro de los géneros tradicionales. Uno de los problemas fundamentales al acercarse a la novela es la tipificación y denominación con que los griegos clasificaron los diferentes géneros literarios. La novela como uno de los géneros literarios más tardíos, nacidos en Grecia, muestra la influencia de géneros anteriores, así como la incorporación de nuevas corrientes literarias, lo que la convierte en un género híbrido, producto de una cultura cosmopolita para la cual no existió una denominación precisa en la antigüedad.

La novela helenística toma esta denominación del término procedente del latín novella: relato novelesco de una obra en prosa en la que se narra una acción fingida en todo o en parte, y cuyo fin es causar placer estético a los lectores con la descripción o pintura de sucesos o lances interesantes, de caracteres, de pasiones y de costumbres,${ }^{1}$ como señalan Millares (1968), García Gual (1972), Rodríguez-Adrados (1994), Rojas (2009), entre otros.

El género recibió aportes de la épica, el drama, la poesía erótica, la retórica, la historiografía y las narraciones de viajes. La novela griega, como género literario, surge en la época helenística y se convierte en una heredera de la épica en su función del carácter narrativo, pero se aleja al ser un relato de carácter ficticio de tema amoroso en un contexto multicultural, político y económico diferente al homérico.

Los autores de novela helenística trabajaron en sus textos los elementos sorprendentes, novedosos e inesperados en las novelas eróticas de amor y aventuras $^{2}$ (Rojas, 2009). Si bien cada autor modifica los elementos básicos, esto se hace sin apartarse de los cánones propios del género: protagonistas de belleza extraordinaria, amor súbito que surge entre ambos protagonistas el matrimonio o la promesa de boda que une a los amantes.

El eje central de la obra es la narración del amor entre una pareja de enamorados de belleza extraordinaria. El encuentro y separación de los amantes, sujetos a aventuras extremas que los separan temporal y geográficamente, los lleva a la superación individual de los obstáculos para lograr la unión/reunión conyugal y el final feliz. Los diferentes autores muestran su originalidad, no en relación con un argumento que en principio es simple, sino al imaginar y plasmar aventuras diversas, escenarios geográficos exóticos, y en ocasiones hechos fantásticos acordes con el gusto del público lector de la época.

Tal como se mencionó, la más antigua de las novelas griegas conservadas de forma íntegra es Quereas y Calírroe. Fue escrita por Caritón de Afrodisias a finales del siglo I. a. de C. El autor de la primera novela de amor y aventuras denomina su obra como un па̉Өos

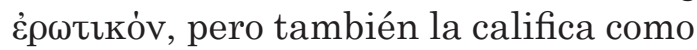
un $\theta \dot{a} \alpha$ toov. Este pathos erotikón se sitúa en Siracusa en la época anterior a la conquista de Asia por Alejandro Magno. El narrador de la historia menciona ser contemporáneo de los hechos 
que narra, aunque menciona elementos contemporáneos: sitúa el río Eúfrates como límite natural del Imperio Persa.

\section{Quéreas y Calírroe: ¿un matrimonio feliz?}

La comedia Nea en el entorno helenístico incorpora el amor como elemento central de los nuevos argumentos. La novela helenística, influenciada por el contexto social y literario, desarrolla el tema del amor de la Nea y lo ubica en el lugar central para desarrollar un argumento caracterizado por múltiples aventuras (Whitmarsh, 2008). La línea argumental de la novela helenística se construye a partir del encuentro y separación súbita de los amantes, y de la superación de pruebas para el final feliz: la unión matrimonial.

El matrimonio se convierte en un tema idealizado en los diferentes géneros de la literatura helenística (Swain, 1999). Las comedias de Menandro, las elegías eróticas de Calímaco y las expresiones del amor romántico en las Bucólicas de Teócrito modifican la concepción tradicional del matrimonio en el mundo helenístico: "Marriage provided the means, and the wife provided the instrument, for securing the allotment (kleros) to the lineage for the next generation" (Guettel, 2003, p. 4).

En la épica y la novela helenísticas, el amor romántico y el amor erótico se convierten en elementos fundamentales para la trama que se narra. En estos géneros literarios, se presenta el matrimonio como el lugar común donde hombres y mujeres alcanzan la felicidad, producto del amor idealizado. En este sentido, es importante señalar, en relación con los espacios y lugares:
"The hegemonic spaces and places which we face today are not only products of forms of economic organization but reflect back at us also - and in the process reinforce- other characteristics of social relations, among them those of gender" (Massey, 2001, p. 183).

El hogar se torna un espacio marital, en el cual la unión matrimonial legitima el control del marido sobre la esposa y los hijos. Mientras las doncellas permanecen bajo la tutela del padre se mantienen seguras hasta el matrimonio; una vez que son dadas al marido, pasan a ser responsabilidad de este. En ambos casos, las mujeres se mantienen recluidas en la casa y cuando salen deben ser resguardadas por los sirvientes del marido.

From the symbolic meaning of spaces/places and the clearly gendered messages which they transmit, to straightforward exclusion by violence, spaces and places are not only themselves gendered but, in their being so, they both reflect and affect the ways in which gender is constructed and understood. The limitation of women's mobility, in terms both of identity and space, has been in some cultural contexts a crucial means of subordination (Massey, 2001, p. 179).

El espacio doméstico sitúa a las mujeres en un lugar protegido por su vulnerabilidad y fragilidad, que contrasta con el espacio público, el ámbito social abierto a la cultura y el poder. La delimitación de estos espacios conlleva una segregación de las mujeres, a quienes se "protege y aísla" simultáneamente, para preservarlas de peligros y ejercer un dominio sobre el cuerpo femenino. 
Así se distribuyeron y limitaron estos espacios simbólicos en áreas físicas contrastantes, como lo fueron el oikos y el ágora. Sin embargo, es importante señalar, como lo enfatizan Cohen (citado en Pérez, 2014): "Lejos de considerar polis y oikos como mundos independientes, la civilización griega, a la vez que separaba y definía claramente sus espacios y características, los articulaba estrechamente, de modo que no tenían sentido el uno sin el otro" (p.15). En este entorno, la novela sitúa a los jóvenes ligados a convenciones y normas sociales que deben respetar mientras permanecen en su patria. Estas normas se invierten cuando viajan de Sicilia a Babilonia. Una vez fuera de Siracusa, el resto de los lugares son considerados foráneos, pues en Jonia, si bien es cierto, hablan griego, los jóvenes se consideran extranjeros en este entorno. En Persia se enfatiza la identidad de Quéreas y Calírroe, más allá de la clase social o género, su etnia y comportamiento heleno.

\section{El encuentro y unión de los amantes}

En Siracusa los espacios y las normas sociales se mantienen acordes con la tradición. La identidad de ambos jóvenes se encuentra sujeta y restringida de acuerdo con la vida política de la polis. Él es un ciudadano con derechos políticos, mientras que ella se considera ciudadana por una denominación étnica asociada con el espacio geográfico de Siracusa: "Males achieved citizenship by birth and service, but a woman's status depends on her father's" (Guettel, 2004, p. 4).

La identidad de Calírroe se establece a partir de su filiación y estatus social. Ella es hija de Hermócrates, el estratega al frente de la defensa de Siracusa contra la expedición naval ateniense a Sicilia: "Reference to a woman as the daughter of a citizen emphasized her legal status and automatically indicated the status of her children"(Guettel, 2004, p. 5). Además, la doncella también es singularizada por su hermosura. Hägg (1991) señala que el nombre Calírroe es parlante: "la hermosa-floreciente (primavera)". La joven es descrita con una "belleza no humana, sino divina, y no la propia de una Nereida o una Ninfa de las montañas, sino de la misma Afrodita Virgen" (1.2.3); es considerada como una "muchacha admirable ornato de toda Sicilia" (1.3.1). Por esta razón, posee una "fama de extraordinaria hermosura" (1.3.3). Ella cumple con cualidades deseables para una esposa ideal, ya que posee "belleza y nobleza de linaje" (1.1.6). Cualidades que la convierten en objeto de deseo, por lo que es pretendida por hijos y reyes de tiranos de los diversos pueblos: Sicilia, Italia, Epiro, entre otros (1.1.2).

En una fiesta pública en honor de Afrodita, cuando Calírroe visita por azar el templo de la diosa, se encuentra frente a frente con Quéreas. En ambos se produce "un sentimiento de amor" (1.1.6). El enamoramiento súbito hace que la joven solicite "ayuda a Afrodita para que le conceda a ese varón que me has mostrado" (1.1.7).

$\mathrm{El}$ autor relata cómo a partir de ese momento: "terriblemente sufría la muchacha a causa de su silencio, ya que sentía pudor de delatarse" (1.1.8); por esta razón, permanecía en el cuarto "tendida en su lecho cubierta con un velo, llorando y guardando silencio" (1.1.14). Calírroe demuestra que la belleza que la caracteriza se encuentra 
aunada a sus cualidades morales, pues ella es honesta y discreta, esconde su dolor y oculta a su familia el amor que siente por el joven.

Por su parte, Quéreas es hijo de Aristón, segundo en Siracusa tras Hermócrates (1.1.3). El joven es descrito como poseedor de hermosa apariencia, a todos era superior; es comparado con Aquiles, Niseo, Hipólito y Alcibíades (1.1.3). Se lo describe "radiante como una estrella" (1.5.2), poseedor de "belleza y nobleza de linaje" (1.1.6), un "joven bien nacido, con noble alma" (1.1.9). En el encuentro con Calírroe, se relata cómo cayó herido por el amor súbito. La herida de amor es descrita por Caritón: "volvió a casa con gran dificultad, al igual que un guerrero valeroso herido mortalmente en combate, que se avergüenza de caer, pero no puede mantenerse en pie" (1.1.7).

La hermosa doncella se convierte en "la causa de su enfermedad", por quien el héroe "corría peligro de perecer por el sufrimiento de su noble alma" (1.1.10). El padre del joven, al conocer el motivo, le pide desistir de su enamoramiento, pues él y Hermócrates son adversarios. Además, ella es pretendida por jóvenes de la nobleza. Desolado el joven solicita la ayuda de Eros y Tyché (1.1.6).

Calírroe se mantiene en el hogar para ocultar el amor y dolor que siente por Quéreas. Por su condición femenina, y de acuerdo con las convenciones sociales, ella no puede expresar abiertamente los sentimientos y el deseo por un hombre. Al ser una doncella noble, debe sufrir en silencio y suplicar ayuda a la divinidad, en este caso a la diosa del amor, Afrodita.

Por contraste, Quéreas sufre su dolor públicamente, no disimula sus sentimientos, al punto de que la colectividad se preocupa por él, así "Se compadecen de su sufrimiento jóvenes gimnasio quienes lo adoraban" (I.1.10). La preocupación social por el dolor del joven ocasiona que el pueblo de Siracusa pida a Hermócrates consentir en la boda I.1.12. Incluso, Eros participa como un líder del pueblo para ayudar al joven enamorado (ver I.1.12). Finalmente, gracias a la intervención de los siracusanos, la boda es autorizada.

De acuerdo con Harvey (1999), los espacios y límites desde una perspectiva de género son importantes debido a que:

[...] women and men, then, grow up with personalities affected by different boundary experiences, differently constructed and experienced inner and outer worlds, and preoccupations with different relational issues. This early experience forms an important ground for the female sense of self as connected to the world and the male sense of self as separate, distinct and even disconnected (citado en Massey, 2001, p. 170).

En el libro I, Quéreas se lamenta como un amante de la elegía; incluso, desea morir primero al enamorarse, luego al pensar en la infidelidad y nuevamente en el momento de la absolución del crimen, un comportamiento alejado de la heroicidad masculina tradicional y propio del adulescens de la comedia Nea. El contraste entre el control que ejerce Calírroe sobre sus emociones y la falta de control de Quéreas, al inicio de la novela, enfatiza la diferencia entre ambos amantes. Mientras la joven controla el espacio social que la rodea, su enamorado muestra una falta total de control emocional en el espacio 
privado y en el público. De Temmerman (2014) señala cómo Calírroe usa un objeto personal, el velo, para mostrar la importancia de controlar las emociones en los diferentes entornos:

She uses it not only to withdraw her beauty from public gaze but also to hide her behavior (she lies crying on a couch, veiled and silent, 1.1.14) is said to result from a sense

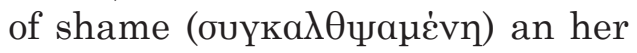
silence is opposed to Chaereas's readiness to inform his parents about his love (1.1.8).

Calírroe se encuentra socialmente condicionada para no traspasar los límites del espacio privado. Por el honor de su familia, no debe externar ningún sentimiento inapropiado, así sufre en silencio. Por el contrario, Quéreas expresa sus sentimientos amorosos en el ámbito privado y público, una actitud que es validada por la sociedad. No obstante, muestra un mayor autocontrol Calírroe que su amado Quéreas, quien produce compasión en amigos y familiares.

El matrimonio muestra cómo las experiencias femenina y masculina se construyen también en un espacio interno para las mujeres y un espacio externo para los varones. Mientras Quéreas se muestra feliz de contraer nupcias con la mujer amada, la experiencia es aterradora para Calírroe. En este sentido, como afirma Massey (2001): "Social space in terms of the articulation of social relations which necessarily have a spatial form in their interactions with one another" (p. 120).

Quéreas escoge a su esposa y el pueblo de Siracusa conoce la identidad de ambos novios. La joven doncella, en el encierro del hogar, desconoce todo detalle del futuro enlace. A pesar de estar enamorada de Quéreas, debe aceptar la decisión de su padre. Por esta razón, cuando Hermócrates le comunica la inminente boda se relata como: "a ella se le desataron las rodillas y el corazón, pues no sabía con quién iba a casarse. Se quedó al punto sin voz y las tinieblas le inundaron los ojos, y poco faltó para que expirara; pero eso a los que la veían les pareció pudor" (1.1.14). La joven asiste pasivamente a la boda, y cumple con el rol que la sociedad le asigna. Afortunadamente, en el momento de la boda frente al pueblo de Siracusa, descubre que el novio es su amado Quéreas (1.1.16).

\section{El matrimonio y los conflictos}

El matrimonio une a los amantes momentáneamente, pues los celos y la envidia de los pretendientes confabulan contra Quéreas y Calírroe. Los pretendientes elaboran un plan: adornan la puerta de los jóvenes esposos con guirnaldas, rocían perfumes, vino y colocan antorchas a medio consumir para simular una serenata frente a la puerta de su hogar, y lograr que el joven esposo piense que su mujer es adúltera (1.2.3).

Si bien, los mismos pretendientes admiran a Calírroe por ser una "mujer íntegra y sin experiencia de sospecha maligna" (1.2.6) consideran que fácilmente podrán hacer dudar a Quéreas de la fidelidad de la joven, ya que él ha sido "educado en los gimnasios y no precisamente inexperto en lo tocante a faltas juveniles, puede fácilmente concebir sospechas y caer en los celos" (1.2.6).

Este será el inicio de las múltiples separaciones que experimentan los 
jóvenes esposos a lo largo de la novela. La primera separación de los amantes ocurre en el espacio del hogar, un lugar donde Calírroe, debería estar protegida y vigilada por su esposo. No obstante, Quéreas se distancia emocionalmente de Calírroe al pensar que esta ha sido infiel. La castidad y la buena fama son fundamentales para la valoración de las mujeres en el mundo griego. La fidelidad femenina brinda no solo fama y gloria individual sino que esta se traslada a la familia y al esposo. Calírroe es considerada en alta estima, no solo por su aspecto físico, sino por su comportamiento; por ello, es considerada como la "corona de Siracusa"(1.2.3).

Ante las evidencias circunstanciales de un posible adulterio, el joven marido se "asombró, pero en cuanto conoció la causa se precipitó dentro y fuera de sí; y encontrando la cámara nupcial cerrada la golpeó violentamente" (1.3.4). Al ver a Calírroe, "cambió su cólera por dolor, y desgarrándose los vestidos se echó a llorar" (1.3.5) "se quedó sin voz, incapaz de no creer lo que había visto, ni de creer lo que no quería" (1.3.5), permanecía "confuso y temblando" (1.3.5).

A pesar de su juventud, Calírroe es consciente de su rango social, su identidad como hija de Hermócrates, esposa de Quéreas y mujer honesta. Por esta razón, ante las falsas acusaciones reacciona como se espera de ella: "como hija de estratego, llena de orgullo, se irritó por tan injusta acusación" (1.3.6). Calírroe se defiende y acusa a su marido de desconfiar por sus acciones y no las de ella, y "cubriéndose con el velo abrió las fuentes de su llanto" (1.3.7). Quéreas se arrepiente de sus sospechas y los amantes se reconcilian dentro de los límites del hogar y en la privacidad del tálamo nupcial. Los personajes experimentan los espacios de diferentes formas. Estos últimos con frecuencia definen las interacciones y el comportamiento de los personajes. En la reclusión del hogar, Quéreas se comporta más como joven enamorado y deja la faceta del marido ofendido.

El oikos en el mundo griego señala un espacio privado en el cual, incluso en su interior, existen espacios como el gineceo y el andrón donde se mantienen las jerarquías de género (Nevett, 1999), el primero un espacio delimitado para las mujeres y el segundo para los varones. El tálamo nupcial es un lugar separado de mundo exterior: un espacio compartido únicamente por los esposos, la privacidad y sacralidad garantiza los juramentos de fidelidad que unen a los amantes después del matrimonio. La preocupación de Quéreas ante una posible infidelidad se encuentra relacionada con la organización espacial que marca diferencias simbólicas y reales, y sobre todo espacios de poder que no pueden traspasarse. Calírroe debe mantenerse fiel a su esposo y la idea de que pueda llegar a mancillar el hogar resulta insoportable para Quéreas. No es, por tanto, estar en un espacio lo que marca la diferencia de género, sino el modo en que se está en ese espacio. (Pérez, 2014, p. 30). En esta división, el tálamo marital es un lugar que debe garantizar no solo la fidelidad femenina, sino la legitimidad de la progenie y, por ende, de la ciudadanía.

\section{La muerte de Calírroe y el fin del matrimonio}

Los pretendientes, al no lograr el objetivo inicial, elaboran un segundo plan $^{3}$ para separar al matrimonio. La reacción de Quéreas ante la "supuesta 
infidelidad" de su esposa no corresponde a lo que se espera de un héroe. Se le representa como un joven a quien el dolor doblega: "Se cubre el rostro y la cabeza con ceniza" (1.4.6), "Se queda estupefacto, con voz débil" (1.4.6) y "Dice que no dañará a Calírroe sino que él se quitará la vida" (1.4.7). En este punto, el joven se aleja de la imagen heroica tradicional y asume el papel del amante abandonado.

$\mathrm{El}$ joven esposo cegado por los celos finge marcharse y acecha la casa durante la noche. Engañado por el plan de los pretendientes entra encolerizado, súbitamente y a oscuras en el tálamo nupcial; reacciona de forma violenta cuando su esposa se le acerca: "no tenía ni voz para hacerle reproches y dominado por la cólera le dio una patada cuando se le acercó" (1.4.12). Calírroe "habiéndole alcanzado el pie justamente en el diafragma, quedó privada de respiración, derribada en el suelo" (1.4.12), por lo que "Calírroe yacía sin voz y sin respiración pareciéndoles a todos la imagen de una muerta" (1.4.12).

La aparente muerte que causa Quéreas a Calírroe no lo hace reflexionar sobre la violencia ejercida sobre su indefensa esposa. Por el contrario, se describe, en el texto, cómo la cólera del joven no disminuye con esta acción. Él después de agredirla se encierra en la cámara nupcial durante toda la noche para interrogar a las criadas sobre la veracidad de la acusación. La actitud de Quéreas muestra a un joven, crédulo, violento e irascible, quien actúa sin reflexionar sobre la veracidad de las acusaciones en contra de la joven.

El testimonio bajo tortura de las criadas aclara la inocencia de Calírroe; solo entonces, el joven marido siente compasión de la muerta. La respuesta de Quéreas es poco heroica porque antes que afrontar las consecuencias de sus actos piensa en acabar con su vida, lo cual no llega a concretar. Esta será una de las primeras, más no la única, ocasión cuando el joven considere la muerte como una salida válida ante el dolor de la situación en la que se encuentra y no desea enfrentar.

El joven marido desesperado se somete a juicio por la "muerte" de su esposa y pide al pueblo ser castigado. La agresión que ocasiona la "aparente muerte" a la protagonista es un hecho que traspasa los límites privados y se convierte en un evento de dominio público en el juicio. Los detalles de la intimidad del matrimonio, así como la agresión y supuesta muerte de Calírroe, dejan el entorno privado del oikos y se convierten en tema de dominio público. En el juicio público, Hermócrates, el pueblo y los jueces lo absuelven del crimen: "todos olvidando a la muerta, se dolieron por el vivo"(1.5.6). Esta actitud demuestra la clara división social que se otorga a la vida, determinada por los roles de género y la objetivación de Calírroe.

No obstante, "Quéreas no se absolvió a sí mismo, sino que deseaba la muerte e ideaba todos los caminos posibles para su fin" (1.5.6). Policarmo, el amigo fiel de Quéreas, es quien cuida de él y evita que el joven acabe con su vida. Quéreas hace públicos sus sentimientos, llora frente a los demás e incluso intenta suicidarse (1.1.7,1.1.10,1.3.5, 1.4.6, 1.4.7,1.4.12, 1.5.6).

Al concluir el matrimonio con la supuesta muerte de Calírroe, la separación inicial entre los amantes no es geográfica pero parece definitiva. Las fronteras entre la vida y la muerte marcan un límite que no puede ser 
traspasado. La separación de los amantes surge a partir de la disrupción del orden marital, un caos provocado por Quéreas. La credulidad del joven ante los falsos rumores de adulterio y la falta de control son las causas de su desgracia.

\section{El entierro público y la separación de los esposos}

Ante el dolor público, expresado por Quéreas, la reconciliación con Hermócrates une a ambos hombres en el dolor por la pérdida de la joven. Juntos deciden enterrar a Calírroe "mientras es bella" y con un "cortejo fúnebre digno de una reina" (1.5.6). La joven es exhibida para el pueblo de Siracusa como un objeto pasivo e inmóvil. Según relata Caritón, ella recibe los honores propios de un rey como premio a su honor, fama y belleza: "yacía envuelta en sus vestidos de boda sobre un lecho recubierto de oro tan bella y majestuosa que todos la comparaban a Ariadna dormida" (1.6.3).

Las comparaciones de la joven siempre la asemejan a deidades o personajes célebres del mito, que contribuyen a su objetivación por causa de su belleza. Para resguardarla se intercambia el encierro del gineceo y la cámara nupcial por la tumba donde permanecerá protegida y oculta de las miradas. Un objeto ya inalcanzable pues no pertenece más al mundo de los vivos.

Caritón narra cómo "Hermócrates añadió, también muchas cosas de su botín de guerra" (1.6.4) y Quéreas: "deseaba, si le fuera posible, quemar su hacienda juntamente con su mujer" (1.6.5). Así, el pueblo compadece aún más al joven marido, pues "de todos los que se iban lamentando, se oía sobre todo a Quéreas" (1.6.5).
Mientras que la "corona de Siracusa" (1.2.3) es admirada y contemplada por última vez, la multitud siracusana muestra la prioridad de la valoración social de lo masculino, el pueblo se conmueve por el dolor del joven irreflexivo y se olvidan las consecuencias de sus acciones impetuosas.

Calírroe por causa de su belleza es enterrada de forma precipitada para evitar que la muerte cambie su aspecto y el estado de inconsciencia en que se encontraba permite que sea enterrada viva. El despertar de la joven sola y en la tumba describe su retorno al mundo de los vivos:

Habiéndose producido por falta de alimento una cierta relajación en la respiración, que le faltaba hasta entonces, comenzó a respirar penosamente y poco a poco. Luego comenzó a mover su cuerpo miembro a miembro, y al abrir los ojos recobró la conciencia como si saliera del sueño, y llamó a Quéreas creyendo que dormía a su lado (1.8.1).

Caritón relata cómo ella "experimenta un nuevo y extraño nacimiento" (1.7.8) pues al despertar se encuentra en una tumba. Si bien, inicialmente llora y se desespera una vez que recuerda los acontecimientos empieza a racionalizar su situación: "estoy enterrada viva sin haber delinquido en nada y voy a morir de una muerte larga" (1.8.4). La reflexión sobre su situación no la hace olvidar su amor por Quéreas. No reprocha a Quéreas la agresión, sino el entierro precipitado, e incluso llega a sentir celos al pensar que él busca una nueva boda.

El espacio liminal donde se encuentra viva en la tumba pero muerta 
para Siracusa es perturbado por la llegada de los piratas, ladrones de tumbas. Esta es la primera prueba que la joven enfrenta lejos del hogar. Si bien Calírroe ha estado siempre protegida por su padre y por su esposo, sola en la tumba muestra su racionalidad al comprender rápidamente los riesgos que corre su vida con los piratas.

Ella sola y abandonada por su familia y esposo recurre a su sentido común y astucia para sobrevivir en un medio hostil. La joven esposa rápidamente valora lo precario de sus circunstancias y, por esta razón, finge ingenuidad ante los raptores para mantenerse viva e incluso finge incluso llorar por el temor de la travesía durante el viaje por mar. Así, ella logra esconder el dolor y la angustia que siente: "A tierra extranjera soy llevada, y voy a tener que ser esclava yo, una mujer de noble linaje" (1.11.3). Calírroe pese a su juventud es hábil en reconocer los peligros del entorno que la rodean y se adapta para sobrevivir.

Calírroe es súbitamente obligada a abandonar la seguridad del oikos y el entorno familiar. Lejos de su patria, debe enfrentar diferentes retos en los entornos geográficos y sociales desconocidos. En la novela helenística, los protagonistas usualmente son separados física y espacialmente, lanzados a correr aventuras, en espacios geográficos alejados del mundo griego conocido. Frente a los lugares desconocidos también enfrentan nuevas jerarquías de poder y clase social por su condición de extranjeros en tierras lejanas.

La estructura de la geografía social se constituye en un elemento de poder que afecta las relaciones sociales en cuanto a clase y etnia. Las relaciones de género y espacio, como bien señala
Massey (2001), determinan los espacios y lugares hegemónicos que reflejan y refuerzan las relaciones sociales $\mathrm{y}$, entre estas, las de género. Así, las acciones de la joven después de que abandona el hogar la alejan del modelo tradicional femenino.

Calírroe es consciente de que, al traspasar las fronteras de su ciudad, pierde el linaje la familia, la seguridad y la protección de Siracusa. Lejos del mundo conocido hasta entonces, ella debe forjar una nueva identidad. Las identidades ficcionales no constituyen una esencia innata; por el contrario, se forman como productos de la cultura humana, a partir de las percepciones de los otros (Whitmarsh, 2011).

El rapto de Calírroe la obliga a cruzar fronteras, al viajar por mar, no solo traspasa los límites geográficos, sino también, de forma simbólica, deja atrás su identidad como hija de Hermócrates y esposa de Quéreas. Calírroe es vendida por los piratas como esclava en Mileto. La joven muestra su astucia ya que, aunque la aflige su nuevo destino, no muestra sus verdaderos sentimientos en público, pues "consideraba su venta más feliz aún que su antigua nobleza, ya que quería librarse de los piratas" (1.13.10).

A solas y en privado, es cuando la joven se queja de su suerte por causa de su amante asesino. Ella continúa enamorada de Quéreas pero no piensa en el suicidio como salida fácil ante una situación que la amenaza. En un escenario adverso donde es vulnerable por su condición femenina, muestra habilidades y recursos para adaptarse al entorno. Una actitud que contrasta con Quéreas quien se mostrará en diversas ocasiones incapaz de soportar los obstáculos que encuentra, 
los cuales logrará vencer gracias a la ayuda de Policarmo.

Calírroe es la típica joven sumisa a quien se objetiviza para el matrimonio, la muerte y la venta: se la da en matrimonio y ella desconoce al novio; se la mata por celos infundados y el asesino es absuelto y compadecido incluso por su padre; se la entierra apresuradamente para que no pierda su belleza; los piratas la toman como botín y es vendida como esclava. Así en repetidas ocasiones es víctima de las relaciones interpersonales de poder (De Temmerman, 2014).

Al llegar a Darsena todos quedan maravillados por su belleza: "quedaron estupefactos, creyendo que estaban viendo a una diosa, pues se decía que en los campos se aparecía Afrodita" (1.14.1). La belleza de Calírroe resulta una cualidad ambigua, porque con frecuencia la sitúa en peligro como objeto de deseo para los varones que quieren poseerla pero también le permite obtener poder sobre sus admiradores, lo que revierte la jerarquía de poder (Egger, 1994). Sin embargo, Calírroe es consciente de que su belleza no es garantía de un mejor destino: "he aquí otra tumba en la que Terón me ha encerrado más desierta aún que aquella" (1.14.4) y situación "fui entregada como un mueble a no sé quienes" (1.14.8).

En Mileto Calírroe es una mujer extranjera, que pierde su libertad e identidad al ser vendida como esclava, una nueva objetivación a la que debe adaptarse rápidamente para proteger su vida. A diferencia de Quéreas, quien enfrenta las aventuras y obstáculos acompañado de su amigo Policarmo, Calírroe únicamente cuenta con su ingenio para salir adelante frente a la adversidad.

\section{Las aventuras en Jonia y Mileto}

El espacio geográfico se constituye en el medio que separa espacialmente a los amantes y eventualmente también posibilita su reencuentro. Los retos que ambos encuentran al cruzar los límites de su Siracusa enfrentan a los amantes a un mundo desconocido. Ellos por el azar son llevados a lugares extraños, exóticos y peligrosos. Al ser extranjeros, carecen de la protección y los recursos que les otorgan la seguridad como ciudadanos de Siracusa. Además, la pérdida de libertad y la condición de esclavitud invierten la jerarquía de poder, por lo que no solo deben adaptarse a un entorno geográfico desconocido sino también a una nueva geografía social, en la cual se les sitúa en una clase inferior.

Los cambios y retos obligan a los personajes a desarrollar habilidades que les permiten evolucionar psicológicamente. El paradigma de la otredad se convierte en su nueva identidad: ella no es más la "corona de Siracusa", reverenciada y admirada, sino una mujer sola en un entorno hostil y desconocido. La construcción del espacio geográfico se encuentra entretejido con las experiencias individuales con respecto al movimiento físico, los cambios y la percepción (Morgan y Stoneman, 1994).

Calírroe experimenta la otredad al perder su identidad de mujer libre, hija y esposa, y asumir su condición de esclavitud. El espacio geográfico en la novela helenística es uno de los elementos fundamentales que permite los cambios de escenario, pues los viajes tienen una función temática y simbólica, la cual va más allá de un simple cambio del entorno (Romm, 2008). Los personajes evolucionan y cambian su 
identidad obligados por las circunstancias, sin olvidar los valores que los definen como griegos.

Calírroe aconsejada por Leonas, el esclavo del nuevo amo, se presenta ante Dionisos a quien relata su historia. El súbito cambio de identidad la obliga a ser previsora por la fragilidad e indefensión de su condición, una extranjera sin familia convertida en esclava. Ella revela su nombre, origen, enterramiento y rapto por los piratas, pero omite los detalles de su falsa muerte y el matrimonio con Quéreas.

La joven logra impresionar favorablemente al nuevo amo: "se admiró Dionisio de la cordura de la mujer" (1.5.10) y pensó: "ni Helena ha sido tan hermosa. Y además esta tiene incluso el poder de persuadir con sus palabras" (2.6.1). En esta cita, se enfatiza la objetivación de Calírroe por su belleza, pero también se alude al poder que ejercen sus palabras, un elemento que usualmente se atribuye a los varones. Además, Dionisio rápidamente descubre otras virtudes cuando ella no acepta sus avances amorosos: "Ni con regalos pues, veía la grandeza del alma de la mujer, ni con amenazas o violencia convencido de que ella elegiría la muerte antes que ser ultrajada" (2.6.8). En este caso, la muerte se señala como salida para defender el honor y no simplemente como una huida de circunstancias dolorosas o adversas.

La situación cambia drásticamente cuando Calírroe descubre que está embarazada de Quéreas. Inicialmente, ella piensa en morir e intenta abortar $(2.8 .7,2.9 .1)$, pues, por su condición de ciudadana siracusana, detesta la idea de tener un hijo de Quéreas que se convertiría en esclavo. Se debate entonces entre sentimientos encontrados hasta que un sueño la convence de conservar al niño (2.9.4), y se persuade para continuar con vida para protegerlo. Por esta razón, acepta los consejos de la criada Plangón para desposarse con el amo y hacerle creer que el hijo es suyo (2.10.1).

El descubrimiento del embarazo, las decisiones y el plan se realizan en el espacio de reclusión del hogar, pues este proporciona la privacidad de los espacios cerrados donde se intensifica la capacidad de reflexión, la toma de decisiones y la planificación de conspiraciones (De Jong, 2012). El espacio del hogar no solo permite ocultar las emociones y el dolor con discreción, sino que permite elaborar una estrategia que tendrá injerencia a nivel público. La boda otorgará un cambio de estatus social para Calírroe, la ciudadanía al hijo de Quéreas y reconocimiento público del niño como heredero de Dionisio.

Una noche, después de celebrada la boda con Dionisio, Calirroe sueña con Quéreas y pronuncia inadvertidamente su nombre. Por esta razón, debe contar la verdad de su malogrado matrimonio a su nuevo esposo. Ella muestra su prudencia al elegir el momento preciso para develar la verdad a Dionisio, ya que este comprende la situación y acepta las explicaciones de la joven.

El niño nace al séptimo mes de la boda y es reconocido por Dionisio como hijo legítimo. El reconocimiento oficial de la paternidad no solo asegura el bienestar del niño, sino la posición de Calírroe en el hogar pues Dionisio: "dejó todo en manos de su mujer y la declaró dueña de la casa” (3.7.7).

Mientras Calírroe enfrentaba sus aventuras en solitario, Quéreas en Siracusa había descubierto la profanación de la tumba y la ausencia de su amada. El joven desesperado decide 
partir en búsqueda de los piratas para recuperar a su amada y es acompañado en la búsqueda por su amigo Policarmo, quien lo consuela pues durante el viaje "Quéreas lloraba con la cabeza cubierta en el fondo de la nave" (3.3.13). Inicialmente, se dirige a Libia y por azar encuentran la barca de Terón a la deriva con todas las prendas y ofrendas de la tumba, excepto a la joven (3.4.6). Bajo tortura Terón relata la venta de Calírroe en Mileto (3.4.6).

De regreso a Siracusa frente al pueblo, Quéreas se mostró "vestido de negro, pálido, cubierto de polvo, como quien acaba de acompañar a la tumba a su mujer no quiso subir a la tribuna" (3.4.4) y "primero estuvo llorando largo rato, y aunque quería hablar no era capaz de hacerlo" (3.4.4). La actitud de Quéreas se aleja de lo heroico para mostrar a un joven dominado por sus emociones. Una vez más cuando la familia y el pueblo le piden esperar una estación más apropiada para partir, el joven intenta suicidarse arrojándose al mar y es nuevamente Policarmo quien lo salva (3.5.1)

Quéreas y Policarmo llegan a Mileto pero al no encontrar a Calírroe, pues son engañados por el esclavo de Dionisio, parten por mar para continuar la búsqueda. Durante el viaje, son víctimas de unos bárbaros que atacan el trirreme y ambos amigos son vendidos como esclavos. La aparente felicidad de Calírroe con su maternidad es momentánea, porque pronto le llegan noticias de la visita de unos extranjeros al templo de Afrodita, en Mileto. Una anciana le relata el evento y la joven se da cuenta de que Quéreas vive. No obstante, Dionisio consigue que unos campesinos relaten ante la joven el episodio del hundimiento del trirreme donde viajaban los extranjeros (3.8.4).
Ella pierde entonces toda esperanza y cae presa de la desesperación (3.10.3,4.1.1) Dionisio preocupado por su esposa y consciente de la imagen del hogar como sinécdoque de la unión matrimonial, comprende que el amor de la protagonista por Quéreas atenta contra este espacio seguro. Así, decide consolar a su mujer, quien se muestra en extremo vulnerable (4.1.2). Dionisio le permite a Calírroe levantar una tumba en honor de Quéreas y realizar un entierro simbólico. Todos los que asisten al entierro se muestran admirados por la belleza de la joven, quien ajena a esta admiración se quejaba ante la Fortuna por haberla convertido junto con su amado "en desterrados" (4.1.12).

Quéreas y Policarmo convertidos en esclavos son enviados a Caria. En este lugar, el joven siracusano languidece de amor y no logra adaptarse a los ultrajes de la esclavitud; es su amigo Policarmo quien lo mantiene con vida (4.2.3). El incidente de una huida de esclavos en la cual no participan los condena a morir en la cruz. Quéreas se muestra desconsolado por su amada y acepta la muerte con resignación. Policarno se queja de su suerte por causa de Calírroe. El administrador piensa que se trata del nombre de una mujer cómplice en la huida y lo lleva ante Mitrídates. Allí Policarmo relata la historia y Mitrídates interviene y evita la muerte del joven siracusano en Mileto.

Mitrídades interviene para ayudar a los jóvenes amantes y aconseja a Quéreas enviar una carta. Desafortunadamente, el estratego de Priene intercepta la carta de Quéreas y así Dionisio evita que Calírroe la lea. El marido indignado piensa que Mitrídades, prendado de la belleza de su mujer 
intenta seducirla, y solicita ayuda Farnaces, gobernador de Lidia. Por esta razón él y Mitrídates son convocados a juicio ante el gran rey persa Artajerjes en Babilonia. Calírroe parte hacia un nuevo destino, en compañía de su esposo, sin conocer las razones del viaje.

\section{Las aventuras en Babilonia y Egipto}

Calírroe se muestra triste al tener que partir a nuevos lugares, pues teme que su belleza le cause nuevas desgracias. Ella se queja de su suerte al tener que atravesar el Éufrates y dirigirse a tierras extranjeras cada vez más lejos de Siracusa: "ya ni siquiera es a Jonia donde me destierras" (5.1.1), "me veo separada de mi patria por el mundo entero" (5.1.1).

Durante el juicio contra Mitrídates, Dionisio no desea que su mujer se muestre en público, pero desafortunadamente cautivados por la fama de su belleza incluso el gran rey desea verla. Se determina que ella comparezca en el juicio público. Calírroe se indigna al conocer las verdaderas razones del viaje a Babilonia y cuando finalmente se presenta al juicio se la compara con Helena en las murallas troyanas frente a los ancianos. En este sentido, como afirma Egger (1998):

The ambiguous nature of the pleasure afforded by the heroine's visual centrality. On one hand it is passive, dependent on the gaze of others.... her optical allure endows the heroine with a special kind of power. Wherever she goes, people fall at her feet (p. 39).

Calírroe, obligada a comparecer de forma pública, se queja de su suerte:
"Estuve muerta y enterrada, violada mi tumba y fui vendida y esclavizada, y he aquí Fortuna que me somete a juicio" (5.5.2). Ella se objetiviza al punto que la identidad de la joven se encuentra determinada en función de quien detenta el poder sobre ella (Egger, 1994, p. 40). La Fortuna es señalada por la joven como la causante de sus desgracias "me hiciste sospechosa de adulterio" (5.5.2) y "con tu calumnia me llevaste a la tumba, ahora al tribunal del Rey. He llegado a estar en boca de todo el mundo en Asia y en Europa" (5.5.3). La joven se siente aún más amenazada que en otras ocasiones, por encontrarse en un país extraño fuera de la Hélade y expuesta de forma pública.

Calírroe muestra una capacidad de adaptación admirable para una joven que antes de salir de Siracusa había estado protegida en el interior del hogar de su padre y su marido. Las nuevas experiencias ponen a prueba la astucia y el autocontrol de la joven. En la adversidad, ella reacciona de forma mucho más positiva que su contraparte masculina frente a los entornos desconocidos.

Finalmente, durante el juicio Calírroe y Quereas, se reencuentran y ella es reclamada por ambos consortes. Quéreas reclama a Calírroe diciendo: "Su padre me la dio a mí" (5.7.5). Dionisio afirma "Y a mí se entregó ella misma" (5.7.5). Mientras tanto "Calírroe estaba de pie, con la vista baja llorando, amando a Quéreas, pero llena de respeto hacia Dionisio" (5.8.6). Además, el gran rey también queda prendado de la belleza de la joven y decide extender el plazo para tomar la decisión.

En esta ocasión, cuando es requerida por el gran rey, ella piensa en el suicidio para escapar solo en el caso de 
que sea necesario y como última instancia ante una violencia más grave (6.6.5). Por segunda vez, la protagonista piensa en el suicidio para proteger el honor y no como salida a la desesperación amorosa. Ante el asombro del eunuco del gran rey por la reacción de la joven, Caritón enfatiza los valores de la identidad griega que contrastan con la etnia de los bárbaros que no comprenden la fidelidad y la virtud de la joven esposa.

La Fortuna interviene a favor de los amantes y, ante una inesperada sublevación de los egipcios, el gran rey decide partir con su comitiva para enfrentarse a los rebeldes. Quéreas permanece en Babilonia cuando Artajerjes se va a Egipto. Dionisio se marcha con el rey y engaña a Quéreas haciéndole pensar que Calírroe le fue devuelta.

\section{Separación y reencuentro de los amantes}

Al sentirse engañados, Quéreas y Policarmo deciden marchar a la guerra para vengarse de Artajerjes. En este nuevo espacio geográfico, Quéreas empieza su transformación cuando deja atrás al enamorado sufriente que no logra controlar sus arrebatos emocionales y en Egipto adquiere el autocontrol que lo convierte en un estratega exitoso.

En el libro sétimo, Quéreas muestra su faceta heroica cuando vence la ciudad de Tiro y luego se convierte en almirante de la flota Egipcia, donde además de su transformación militar adquiere una dimensión retórica (De Temmerman, 2014). A partir de este momento, el héroe habla de forma persuasiva y convence con sus arengas al ejército egipcio (7.2.2, 7.2.3, 7.3.3). Incluso Calírroe reconoce el cambio del joven al compararlo con el gran rey: "[...] evoques a contrast between Chaereas and Artaxerxes (and the persians in general) by drawing attention to the fact that Syracuse could not be beaten even by the Athenians, who did beat the Persian King at Marathon and Salamis" (De Jong, 2012, p. 484).

Finalmente, Quéreas vence al ejército naval de Artajerjes y se comporta de acuerdo con su estirpe y etnia. Al apoderarse de comitiva del rey, en Arados ignora que Calírroe se encuentra allí, en compañía de las mujeres de la casa del gran rey. Por su parte, Calírroe ante la adversidad es quien consuela a la reina persa "como griega educada y no inexperta en los males, era la que mejor podía consolar a la reina" (7.6.5).

El énfasis en los valores, la educación y la cultura helena es constante a lo largo de la novela para demostrar cómo la etnia griega prevalece en las acciones de los protagonistas aun en condiciones extremas. Así cuando le anuncian a Calírroe que el navarco la hará su mujer se niega a continuar: "Mátame antes de anunciarme eso. No aceptaré un matrimonio, lo que pido es la muerte" (7.6.8); además, se niega a embarcarse junto con las otras mujeres.

Quéreas es informado de la situación y pide que no violenten a la mujer, cuando acude al lugar se reencuentra con Calírroe.

El feliz reencuentro es interrumpido por las noticias de la inminente llegada del gran rey a Arados. Quéreas pretende enfrentarse a Artajerjes pero por consejo de Calírroe calma su ímpetu: "si haces público esto, levantarás gran hostilidad contra ti cuando se enteren todos de ello y te despreciarán" (8.2.4). Calírroe da muestras de su prudencia cuando aconseja a su marido no 
enfrentar al gran rey. Así abandonan el lugar y se dirigen a Chipre para regresar a Siracusa.

Quéreas eufórico por sus victorias ofrece como esclavas para Calírroe a las nobles persas. No obstante, Calírroe no olvida la sensatez en ningún momento: "No permitan los dioses que me sobrevenga tal locura como para tener por esclava a la reina de Asia, sobre todo después de haber sido su huésped" (8.3.2). Él autoriza a su esposa para disponer de las mujeres y el botín. Ella pide que sean devueltas a Artajerjes y su acción es reconocida por la reina: "En todo has actuado conmigo con justicia. Has dado muestras de un carácter excelente digno de tu belleza" (8.3.14). Una vez más Calírroe da muestras de la nobleza de su linaje al respetar la xenia, proporcionada antes por Estatira.

\section{El regreso a Sicilia}

Antes de partir, Calírroe escribe a Dionisio una carta agradeciéndole su protección y rogándole por el cuido del niño. Ella le pide que no tenga madrastra y que lo case con su hija cuando crezcan. Además, desea que cuando sea un adulto lo envíe a Siracusa a conocer a su abuelo materno (8.4.6). La joven también pide a Estatira que proteja a su hijo y como favor le entrega la carta dirigida a Dionisio para que se la haga llegar (8.4.7). De esta forma muestra su prudencia, al ocultar la acción a Quéreas para no despertar sus celos.

El regreso al lugar de origen es concedido por Afrodita y se convierte en un motivo temático como afirma De Jong (2012, p. 489): function of space is further underlined by a remark made by Aphrodite at the end of the story: she judges that Chaereas has made 'honorable amend to Love' which consists precisely in wandering the world: 'having harassed by land and sea the handsome couple she had originally brought together, she decided now to reunite them (8.1.3).

El retorno de los jóvenes muestra la evolución de Quéreas cuando logra llevar a feliz término la travesía de regreso hasta Siracusa. Atrás queda el joven enamorado y desesperado cuyos intentos de suicidio fueron frustrados continuamente por su falta de autodeterminación (Whitmarsh, 2015). El hombre que regresa a Siracusa es un héroe que ha probado su valor en batalla y espera el reconocimiento de sus conciudadanos.

Quéreas ordena adornar los trirremes para entrar a Siracusa, la embarcación llevaba una tienda en la parte superior cubierta con paños de Babilonia. Él es consciente de que regresa con la "corona de Siracusa" como vencedor, ya que él la ha devuelto al hogar y así la muestra a los ciudadanos: "descorrieron de repente las cortinas y quedó tendida en un lecho de oro, vestida de púrpura de Tiro, y Quéreas, reclinado junto a ella, con las enseñas de estratego" (8.6.7).

En Siracusa, los espacios, la identidades, las fronteras y los límites son restablecidos pues desde el inicio como refiere Egger (1994):

Calirrhoe is the focus of the plot, which revolves around her and which, indirectly, she drives. Not only is he on-stage throughout long sections of the action, but even when she is absent, the thoughts feelings 
and activity of all the other characters are directed toward her. Most strikingly the gaze of the other is always on her: the gaze of men, women, the public, the narrator" (p. 36).

Es necesario, entonces, que ella sea ocultada para que Quéreas pueda brillar: "A Calírroe a quien suponían fatigada por el viaje y sus desgracias, la sacaron del teatro una vez que hubo saludado a su patria" (8.7.3). De vuelta a Siracusa, los jóvenes deben retornar a las esferas de acción respectivas:

Foreign places where the adventures take place are opposed to the closed realm of the house from which the protagonists set out in the beginning of the story and to which they return at the end.This opposition is first established in the beginning of the novel and taken up at the very end (De Jong, 2012, p. 489).

Por su parte,el joven estratega relata de forma pública las aventuras vividas por ambos: "a Quéreas le retuvo la multitud, que quería oír todo el relato de lo ocurrido en su ausencia" (8.7.3). Omite el protagonismo y el valor de Calírroe al cambiar eventos (razones del matrimonio de Calírroe, el crédito de la liberación de Estatira y, por ende, la amistad con Artajerjes) para brillar como héroe absoluto. Al final de la novela, Quéreas es un orador que manipula el relato de las aventuras con fines retóricos (De Temmerman, 2014). De regreso al hogar, Quéreas asume el lugar que le corresponde por su condición y linaje. Por su parte, Calírroe retorna a la reclusión, el encierro y la protección en la privacidad del hogar.

\section{Conclusiones}

El retorno de los amantes a la Hélade supone un regreso a los límites geográficos y sociales que comprenden los espacios de lo femenino y lo masculino. El protagonismo que adopta el personaje de Calírroe en el texto de Caritón aporta una innovación en el tratamiento de los personajes femeninos y la heroicidad en la novela helenística. Sin embargo, Calírroe al final de la novela muestra un comportamiento tradicional, debido a que la transformación heroica que demuestra fuera de la Hélade es temporal. El retorno al hogar y a la Hélade supone un regreso a las acciones y los valores sociales establecidos en el mundo griego.

A lo largo de los seis primeros libros, Quéreas ocupa un lugar secundario, ya que su comportamiento no corresponde con los modelos de heroicidad masculina tradicional. En el relato público de las aventuras, Quéreas oculta el protagonismo de Calírroe y magnifica sus acciones. Las hazañas del joven en los dos últimos libros de la novela le permiten al protagonista desarrollar las hazañas militares y el valor propios del paradigma heroico tradicional para situarse en el lugar central de la novela al concluir el texto.

El final feliz, con el regreso de los amantes a Siracusa, restablece el orden en las relaciones sociales. Una vez que cruzan las fronteras geográficas, ambos retornan a los espacios simbólicos determinados socialmente. Quéreas y Calírroe recobran su identidad en la Hélade y las relaciones de poder vuelven a la normalidad.

La heroicidad femenina y masculina en la novela de Caritón modifica e, incluso, invierte los paradigmas tradicionales en los espacios limítrofes de la Hélade y más allá de sus fronteras. 
El regreso a Siracusa reafirma la condición de género y los espacios de acción de los jóvenes esposos. La heroicidad femenina en la novela de Caritón asume un rol protagónico fuera de la Hélade, con una protagonista que muestra las habilidades y los recursos considerados más afines a los varones. Quéreas muestra una faceta más feminizada al sufrir por amor, desear la muerte ante los obstáculos y necesitar de la ayuda constante de Policarmo aun en Siracusa. Las aventuras fuera de la Hélade muestran cómo Calírroe desarrolla habilidades que le permiten sobrevivir sola en espacios alejados, sin olvidar su identidad pero adaptándose a las circunstancias. No obstante, este comportamiento no se refleja de forma pública al regreso, puesto que para cumplir con los roles sociales imperantes debe asumir la pasividad, sumisión y silencio propios de las mujeres en el mundo griego antiguo.

En Grecia, los protagonistas dejan atrás la esclavitud y el exilio. Calírroe retorna a la protección del hogar convertida en madre, en una mujer prudente y astuta que conoce su lugar en la sociedad. Quéreas se asume como adulto, un héroe militar y un líder para la ciudad. La identidad de ambos se establece y confirma de acuerdo con las normas sociales del mundo griego.

\section{Notas}

1. Las denominaciones de la novela varían en función de la materia fundamental que constituye su argumento; así se habla de distintos tipos de novela: bizantina (aventuras XVI y XVII), gótica (misterio y terror $\mathrm{XVIII)}$ histórica, pastoril (siglo oro), picaresca (XVI y XVII) y rosa (Rojas, 2009).
2. En relación con la novela, Plutarco afirma: "cuando el arte poética carece de la verdad, entonces principalmente emplea variedad

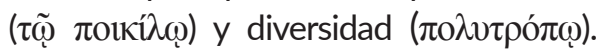
Porque el cambio súbito es lo que da a las historias los elementos de lo emocio-

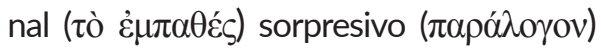

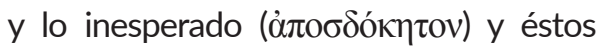
son atendidos con un gran asombro $y$ disfrute; pero lo simple ( $\dot{\alpha} \pi \mathrm{\alpha} \lambda \tilde{v} \varsigma$ ) es no-

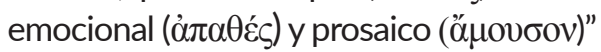
(Plutarco, Mor., 25d).

3. Los pretendientes contratan a un parásito que se convierte en amante de la criada favorita de Calírroe. En la palestra, el viejo parásito se finge amigo de Quéreas y le cuenta el supuesto adulterio de Calírroe. Así, cuando Quéreas lo ve entrar en su casa por la noche, piensa que es Calírroe (1.4.6).

\section{Bibliografía}

Caritón, A. (1979). Quéreas y Calírroe. Madrid:Gredos.

De Jong, I. (2012). Space in Ancient Greek Literature. Reino Unido: Oxford University Press.

(2014). Narratology and Classics. Studies in ancient Greece narrative. Reino Unido: Oxford University Press.

De Temmerman, K. (2014). Crafting Characters. Heroes and Heroines in the Ancient Greek Novel. Reino Unido: Oxford University Press.

Egger, B. (1994). Looking at Chariton's Callirhoe. En Morgan, J. y Stoneman, R. (1994) Greek Fiction. The Greek Novel in Content. Londres: Routledge.

García, G. (1972). Los orígenes de la Novela. Madrid: Istmo.

Guettel, S. (2004). Landscapes, Gender and Ritual Space. The Ancient 
Greek Experience. California: University of California Press.

Hagg, T. (1991). The Novel in Antiquity. California: University of California Press.

Massey, D. (2001). Space, Place and Gender. Minneapolis: University of Minnesota.

Millares, C. (1968). La novela en la antigüedad clásica. Barcelona: Nueva Labor, S.A.

Nevett, L. (2010). Domestic space in classical antiquity. Cambridge: Cambridge University Press.

Morgan, J. y Stoneman, R. (1994). Greek Fiction. The Greek Novel in Content. Londres: Routledge.

Pérez, M. (2014). Entre la casa y el ágora: género, espacio y poder en la polis griega. En http://www. scielo.org.ar/scielo.php? script $=$ sci a r t t ex t \& p i d = S 1669 $57042014000100001 \& \operatorname{lng}=\mathrm{es} \& \mathrm{nrm}$ $=$ iso
Plutarco (2003). Obras Morales y Costumbres vol. X (Moralia). Madrid: Gredos.

Rodríguez, F. (1994). Raíces griegas de la cultura moderna. Madrid: Gredos.

Rojas, L. (2009). Novela Griega: lo maravilloso y lo extraordinario. México: Revista Nova Tellus., vol. 27, n. ${ }^{\circ}$ 1, 2009, pp. 229-245. En http://www.scielo.org.mx/scielo.php?script=sci_arttext\&pid $=$ S0185-30582009000100008

Swain, S. (1999). Oxford Readings in The Greek Novel. Reino Unido: Oxford University Press.

Whitmarsh, T. (2008). The Greek and Roman Novel. Reino Unido: Cambridge University Press. (2015). Narrative and Identity in the Ancient Greek Novel. Returning Romance. Reino Unido: Cambridge University Press. 